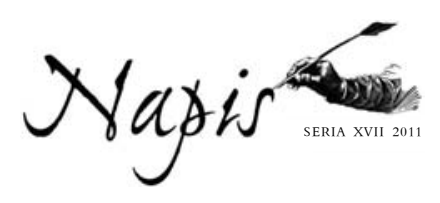

\title{
Jawne i ukryte w literaturze i kulturze
}

W $\begin{aligned} & \text { iniejsza, XVII seria „Napisu”, zogniskowana wokół tematu Jawne i ukryte } w \text { lite- } \\ & \text { raturze } i \text { kulturze, zawiera opracowane materiały, przygotowane zrazu w formie }\end{aligned}$ wystąpień na konferencji (17-19 maja 2011 r.), poświęconej pamięci Profesora dra hab. Janusza Maciejewskiego, od 1994 roku założyciela i redaktora naczelnego naszego pisma.

Tak nagle odszedł od nas Mistrz i Przyjaciel zarazem, któremu z okazji jubileuszu osiemdziesięciolecia ofiarowaliśmy poprzednią serię tematyczną Literatura i rytuaty! Nie zdążył się nią nacieszyć, nie zdążyliśmy z Nim o niej porozmawiać...

Trudno pogodzić się ze śmiercią kogoś tak bliskiego sercu, z odejściem człowieka o wyjątkowej osobowości, który był dla nas zarówno nauczycielem, prawdziwym autorytetem, jak i pozbawionym jakiegokolwiek dystansu partnerem w rozmowach. Zawsze pogodny, właściwie oceniający znaczenie spraw pozornie tylko ważnych, uczył radości życia, wielostronnego wykorzystywania swoich możliwości. Inspirował do przemyśleń i badań, niestrudzenie kierował rozwojem naukowym, wytyczając dotąd nieodkryte ścieżki. Europejskiej klasy badacz literatury i jej różnorodnych kontekstów, zasłużony szczególnie na polu literatury Oświecenia i Pozytywizmu, pełen energii erudyta, patriota ceniący nade wszystko wolność i suwerenność, wykazujący w obronie tych wartości odwagę i poświęcenie, wychowawca młodzieży akademickiej — należał do wielu środowisk, więcej — często był duszą wielu środowisk. Na Uniwersytecie Warszawskim i w Instytucie Badań Literackich PAN Profesor Janusz Maciejewski stworzył wokół siebie „Potężną Gromadkę” — grupę młodych ludzi, pełnych pasji naukowych, chętnych do zainicjowania i rzetelnego wykonania różnorodnych projektów (naukowych, literacko-wydawniczych, publicystycznych). Zainteresował ich literaturą okolicznościową i użytkową oraz przekazał im swój wielki entuzjazm dla niedocenianych dotąd „obszarów trzecich” literatury. W tym właśnie gronie w 1994 r. powołany został do życia „Napis”, pismo od początku wysoko oceniane, dające możliwość dyskusji, ścierania poglądów i opinii (przez starannie zorganizowane konferencje, poprzedzające przygotowywanie poszczególnych roczników), wreszcie — dające szanse publikacji wartościowych rozpraw skupionych wokół wspólnego tematu. Czas mijał. 
Członkowie „Potężnej Gromadki” dojrzewali, zdobywali stopnie naukowe, rozpoczynali samodzielną karierę, podejmowali pracę w różnych instytucjach i uczelniach, lecz ciągle czuli się i czują się nadal wychowankami Profesora. Dołączali do nich stopniowo kolejni młodzi, zwabieni niekonwencjonalnymi metodami pracy i urokiem literatury dawnej, z której — jak się okazywało pod czujnym okiem Profesora — tak wiele można wyczytać. Wielu z nich chce kontynuować, choćby w pewnej części, prace swego Nauczyciela i Mistrza. Jednym z takich miejsc, gdzie jest to możliwe, jest redakcja "Napisu”.

Na pewno jedną z ważniejszych sił napędowych i sprawczych „Napisu” była siła Profesora Janusza Maciejewskiego jako Redaktora Naczelnego. Tego zawsze będzie brakować, jednakże chcemy rocznik wydawać i rozwijać, przede wszystkim dlatego, że takie było również pragnienie Profesora. Ponadto znamy wartość i rangę tego, co w tym jednym z wielu zakresów swej aktywności Profesor nam przekazał. Zostawił mianowicie rzecz bezcenną: profil i charakter pisma, a co za tym idzie: znakomitych Autorów, wiernych Czytelników, a także (mamy taką nadzieję): wielu sprawdzonych Przyjaciół, którzy z sympatią będą sekundować naszym przedsięwzięciom.

„Czas ucieka”, tymi słowami rozpoczął Profesor artykuł wstępny serii XV rocznika zatytułowanej Umysty zniewolone. Literatura pod presja. Dając wyraz radości z powodu tej „całkiem poważnej piętnastki”, zasygnalizował również potrzebę autorefleksji i spojrzenia wstecz na dotychczasową pracę współredaktorów i współautorów pisma, dokonał syntetycznej oceny wydanych dotąd tomów, akcentując, że zwłaszcza od 2003 roku były one monografiami wybranych zjawisk i problemów literackich oraz kulturowych. Podkreślił też to, co przyświecało Mu od samego początku — że badanie twórczości okolicznościowej i użytkowej, prowadzone w obrębie macierzystego dla tych nurtów literaturoznawstwa, wymaga też wsparcia ze strony innych pokrewnych dyscyplin naukowych.

Redakcja w zmienionym nieco składzie osobowym pragnie to kontynuować. Kolejne roczniki będą w dalszym ciągu tomami monograficznymi. Nie zrezygnujemy przy tym ze stałego działu Varia, mieszczącego teksty i artykuły luźniej związane z tematem głównym tomu. Chcielibyśmy również stworzyć też nowy dział: Errata, gdzie zamieszczane będą materiały, których celem będzie wskazanie, omówienie i skorygowanie różnego rodzaju błędnych opinii, ustaleń, wymagających korekty, pokutujących od wielu lat błędów faktograficznych i interpretacyjnych, tekstowych, w tym edytorskich.

Materiały do kolejnych tomów pisma będą gromadzone w dalszym ciągu pod jednym wybranym, dominującym hasłem. Do realizacji tych tomów będziemy zachęcać przede wszystkim historyków i teoretyków literatury. Będziemy zapraszać do wspólpracy również reprezentantów innych nauk humanistycznych — m. in.: języko- 
znawców, historyków, antropologów, socjologów - ale nie dlatego, by prezentowali zagadnienia interesujące głównie ich środowisko, lecz aby pochylili się z uwagą nad wybranymi problemami, wiążącymi się (ze względów historycznych, kulturowych, socjologicznych, obyczajowych etc.) z literackimi tekstami okolicznościowymi i użytkowymi. Może się też zdarzyć, że jakiś rocznik zdominują merytoryczne rozważania uwzględniające punkt widzenia i ustalenia innych nauk humanistycznych. Na ostatnim zebraniu Redakcji postanowiliśmy, ze spróbujemy tego od razu, w następnej, XVIII serii, która zostanie poświęcona tematowi Tabu $i$ wstyd, tym bardziej, że może on stanowić swoistą kontynuację i dopełnienie tematu: Jawne i ukryte $w$ literaturze i kulturze, zaprezentowanemu w tomie XVII, który oddajemy właśnie do rąk Czytelników. Sądzimy, że współpraca z badaczami historii obyczajów oraz postawienie w centrum kategorii „tabu” obyczajowego umożliwi szersze uwzględnienie i dokładniejsze oświetlenie zwłaszcza spraw „ukrytych” — traktowanych z określonych powodów, w różnych okresach, jako wstydliwe lub grzeszne.

Kolejnym proponowanym przez Redakcję tematem będzie Historia i rodzina. Tu chcielibyśmy położyć nacisk na sposoby „oswajania” historii, nierzadko dramatycznych wydarzeń, w tym - na różne metody przezwyciężania traumy spowodowanej przez wydarzenia, najczęściej rzutujące w sposób tragiczny na dzieje rodziny, relacje wewnętrzne (między członkami) i zewnętrzny obraz rodu (status materialny i społeczny). Warto też zwrócić uwagę, że te doświadczenia te niekiedy owocowało przedwczesną dojrzałością, koniecznością dokonywania trudnych wyborów, a ostateczne efekty inwazyjnego wkroczenia historii w ludzkie domostwa były nie tylko negatywne ( $\mathrm{m}$. in. ból, deprecjacja wartości, demoralizacja), ale również pozytywne (samodzielność, zaradność, nowe perspektywy), choć także okupione cierpieniem (np. z powodu rozstania, wyjazdu, osłabienia lub zaniku więzi emocjonalnych).

Wieloaspektowe rozważania tej interesującej problematyki literatury okolicznościowej i użytkowej oraz zaskakujące odsłony różnorodnych faktów i zjawisk, które na przestrzeni wielu wieków (od Średniowiecza po Wiek XX) decydowały o inspiracjach tego rodzaju literatury lub stanowiły jej zaplecze - to obecnie znak rozpoznawczy czasopisma „Napis”. Przyczynili się do tego: całą mocą swej fascynacji Redaktor Naczelny — Profesor Janusz Maciejewski, ponadto gejzer energii, Zastępca Redaktora Naczelnego — obecnie już Profesor, Jacek Wójcicki (który po latach rzetelnej pracy postanowił przekazać obowiązki, lecz nadal służy redakcyjnym kolegom radą i pomocą), Sekretarz Redakcji - Agata Grabowska-Kuniczuk oraz Ich wierna redakcyjna Koleżanka — Agnieszka Bąbel oraz pozostali zasłużeni członkowie Redakcji. W dużej mierze przyczyniła się do tego „wielogłosowość” konferencyjnych wystąpień i wydrukowanych później rozpraw Autorów, rozumiana jako udział w realizacji danego tematu obok badaczy literatury przedstawicieli pokrewnych dyscyplin naukowych. Jednakże w piśmie od samego początku najistotniejszą rolę odgrywały rozprawy znawców literatury, szczególnie zaciekawionych tekstami okolicznościowymi oraz użytkowymi 
(o charakterze oficjalno-publicznym i towarzysko-prywatnym). W dalszym ciągu głównym przedmiotem zainteresowania Redaktorów i Autorów „Napisu” będzie więc literatura okolicznościowa i użytkowa. Liczymy na współpracę naszych znakomitych Autorów, którzy regularnie nadsyłali swoje materiały i brali udział w dociekliwym rozpoznawaniu nieznanych lub mało znanych przestrzeni „obszarów trzecich” literatury. Do udziału w naszych projektach serdecznie zapraszamy również nowych Autorów.

Numer niniejszy, który oddajemy do rąk Czytelników, zdaje się dobrze odzwierciedlać najważniejsze walory koncepcji pisma, wypracowanej dzięki wiedzy i doświadczeniu Profesora Janusza Maciejewskiego oraz zaangażowaniu Jego współpracowników i uczniów. Koncepcja poświęcenia rozważań oraz interpretacji literatury tematowi Jawne i ukryte... wywiedziona została przez nas z refleksji nad najważniejszymi osiągnięciami teoretycznoliterackiej, a także historycznoliterackiej metodologii ostatnich kilkudziesięciu lat. Doszliśmy wspólnie do wniosku, że niezależnie od wielości nowych teorii, a tym samym — perspektyw interpretacyjnych (psychoanaliza, socjologia literatury, hermeneutyka, semiologia i strukturalizm, „krytyka tematyczna” i psychokrytyka, poststrukturalizm i dekonkstrukcjonizm, koncepcja „czystej lektury” Paula de Mana) wszystkie służyły w zasadzie jednemu: odnalezieniu i odkodowaniu potencjalnie obecnego pod jawnym, czytelnym tekstem, ukrytego przekazu. Czy rzeczywiście do takiego odkrycia istotnych treści doszło, a jeśli tak, to jaką prawdę o człowieku - prawdę niekoniecznie logiczną i celowo odsłanianą przez twórców, bo to, co ukryte, rządzi się przecież innymi prawami, niż tekst jawny — ukazał nam ów zapoznany wcześniej poziom tekstu? Czy jest to wiedza budująca, czy też może raczej zespół prawd pesymistycznych, niechcianych, o których wolelibyśmy nie wiedzieć?

Z tej dwuznaczności szeroko rozumianej „hermeneutyki podejrzenia” zdają sobie sprawę wszyscy badacze literatury. Stąd też wiele artykułów zgromadzonych w niniejszym tomie rzeczywiście zawiera w sobie pierwiastek weryfikacji nowych metod i hipotez w odniesieniu do konkretnych przekazów literackich bądź użytkowych. Jest tak choćby w przypadku tekstów: Kamili Tuszyńskiej, która stosuje współczesną teorię przekazu informacji w celu odkrycia w jednym z komiksów Neila Gaimana opowiadania zakodowanego jakby na niższym poziomie, niż zwykła płaszczyzna komiksowej narracji; Agnieszki Bąbel, wykorzystującej antropologię literatury dla wyśledzenia osobliwości prawnych i obyczajowych, obecnych w dziewiętnastowiecznych powieściach; Agaty Grabowskiej-Kuniczuk, stosującej do wybranych powieści Prusa metody wyrafinowanej biografistyki.

Prawdą jest jednak również to, że najlepiej bodaj tego typu „dekodującej” lekturze poddają się teksty w szerokim rozumieniu współczesne (a zatem pochodzące z ubiegłego wieku lub z bieżącego stulecia). Widać to na przykładzie interesujących konstatacji Anity Frankowiak, która proponuje w swoim artykule perspektywę interpretacji prozy Andrzeja Stasiuka, związaną z metodologią badań kulturowego pogranicza. Tekst Wiesława Ratajczaka o Josephie Conradzie udowadnia z kolei użyteczność elemen- 
tów metody studiów postkolonialnych, połączonych tu umiejętnie z analizami Hanny Arendt fenomenu „banalności zła” w lekturze tekstu autora Jądra ciemności, odmiennej jednak od propozycji Edwarda Saida. Twórczością Conrada zajął się także Marek Pacukiewicz, który badał nie główny korpus dzieł tego autora, lecz pisane przez niego przedmowy, aby skonstatować: „opowiadając nam pozornie o sobie, tak naprawdę pisarz opowiada o kontekstach, które ukształtowały go zarówno jako osobę, jak i autora”. W analizie literackiej skuteczne okazuje się odczytywanie zawiłych relacji alegorezy, o czym — w odniesieniu do tekstów z zupełnie różnych epok — przekonują Marzena Wydrych-Gawrylak oraz Edyta Rudolf (przy czym pierwsza z nich zajmuje się emblematami z epoki baroku, druga — powieścią Limes inferior dwudziestowiecznego pisarza fantastycznonaukowego, Janusza Andrzeja Zajdla). Okazuje się również, że kodowaniu tekstu „ukrytego” w tym, co „jawne” służyć może zabieg genologiczny, polegający na nadaniu formy kołysanki utworowi, którego zawartość semantyczna niekoniecznie zgadza się z tak dobraną formą, co udowadnia Katarzyna Wądolny-Tatar w swoim artykule o roli kołysanki w liryce współczesnej. Podobnym tematem zajmuje się Beata Utkowska, która w kontestacjach i prowokacjach pokolenia poetów „bruLionu” odkrywa sfrustrowaną potrzebę ideału i moralnej hierarchii.

Najbliżej źródłowego sensu kojarzonego zwykle z fenomenami kodu lub szyfru są Krystyna Maksimowicz, Przemysław Śniadała, Iwona Maciejewska i Marcin Kuźma. Artykuły te udowadniają, że skomplikowane formy kodowania informacji przeznaczonej dla wybranych odbiorców były nierzadko stosowane w literaturze staropolskiej i oświeceniowej; równie często kodów lub szyfrów używano w celach, chciałoby się rzec, „ponadczasowych” — na przykład w korespondencji miłosnej. Wymienione powyżej teksty ukazują również przydatność metod dekodowania i wielorakiej analizy szyfrów w pracy edytora literatury dawnej.

Redakcja rocznika pozwala sobie wyrazić przekonanie, że zebrane w serii XVII artykuły odpowiadają na pytania, które zadaliśmy sobie w trakcie formułowania koncepcji numeru naszego pisma: o to, co zyskują badacze dzięki czytaniu „przekazów ukrytych”, a także o sposoby wzbogacania zasobów kultury dzięki relacji między ,jawną” i „ukrytą" warstwą tekstu, a wreszcie — o skutki odkodowania tego, co „ukryte” w literaturze? Pozostaje żywić również nadzieję, że opinię tę podzielą nasi Czytelnicy.

Barbara Wolska i Marek Pąkcinski 